\title{
CHICKEN EGG WHITE - CHARACTERISTICS OF ITS PROPERTIES AND THE PROSPECTS FOR FUNCTIONAL FOODS DEVELOPMENT
}

Isabella L. Stefanova*, Anastasia Yu. Klimenkova, Liudmila V. Shakhnazarova, Vladimir K. Mazo

All-Russian Scientific Research Institute of Poultry Processing Industry - Branch of the Federal State Budget Scientific Institution Federal Scientific Center "All-Russian Research and Technological Poultry Institute" of Russian Academy of Sciences, Rzhavki township, Moscow region, Russia

Keywords: egg white, gelation, biological value, functional foods, essential elements, polyphenols

\begin{abstract}
The overview presents the literature data and the results of our own research on prospects of using the chicken eggs as the basis of functional foods. The composition of chicken eggs and their components, characteristics of egg white proteins properties are presented thereto. The biologically active compounds included into egg composition are analyzed. The data on the biological value of egg white are given. The characteristic of egg white foaming ability is presented. It has been shown that the ability of proteins to form stable intermolecular structures, especially with partially denaturated proteins, allows them forming viscoelastic superficial films that ensure foam stability. The high foaming ability of chicken egg protein macromolecules is directly related to their interphase properties, $i$. e. the ability to form interphase layers at the "liquid - gas" interface. The foaming properties of the various egg proteins are not equal, and therefore they contribute to foaming properties at various extents. The model of egg white proteins gelation is considered and the factors influencing the gelation process are described. It has been shown that very important changes in proteins properties are caused by denaturation. The proteins lose their ability to hydrate; the protective aqueous shell around the globules disappears, the proteins stick together, grow larger and lose solubility. This process is called coagulation. The influence of denaturation and aggregation on variations of protein properties is described below. Data on protein fortification with functional ingredients (calcium, iodine, plant polyphenols) and creation of functional egg and meat foods are presented here.
\end{abstract}

\section{Funding:}

The research was supported by state assignment of All-Russian Scientific Research Institute of Poultry Processing Industry Branch of the Federal State Budget Scientific Institution Federal Scientific Center "All-Russian Research and Technological Poultry Institute" of Russian Academy of Sciences, scientific research No. AAAA-A20-120010690002-3.

\section{Introduction}

The priority task of state policy in our country in sphere of nutrition is development of health-improving foods production in order to preserve and enhance the health of population, to prevent diseases caused by insufficient and unbalanced nutrition. The practical implementation of this task assumes, in particular, development, production and supply of wide range of health-improving foods to the domestic consumer market, including functional foods, in accordance to appropriate regulatory and methodological provisions harmonized with international requirements.

The concept of healthy nutrition assumes an increase of efficiency of nutrition factor to the preservation and improvement of public health within the state. This factor provides necessity for development of biotechnologies, targeted to foods modifying by including ingredients of high biological and nutritional value. This leads to creation of an expanded range of functional foods (FF).

The promising source of food raw materials with high biological FF value are chicken eggs. Chicken eggs contain all food and biologically active substances necessary for healthy development [1]. Chicken egg is a natural functional food; it is a unique source of numerous substances of high biological and nutritional value due to significant content of protein balanced in amino acid profile. It contains a complete lipid complex, wide range of macro- and microelements, and vitamins. The average chemical composition is constant, fluctuations in the content of eggs, laid by one species of poultry, depend on the diet of layers (which is especially peculiar for lipid fraction) (Table 1) [2].

Table 1. Chemical composition of a chicken egg

\begin{tabular}{|c|c|c|c|c|c|}
\hline \multirow[b]{2}{*}{$\begin{array}{c}\text { Compo- } \\
\text { nents }\end{array}$} & \multicolumn{5}{|c|}{ Mass fraction, $\%$} \\
\hline & Moisture & Protein & Fat & 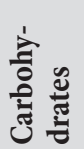 & 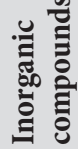 \\
\hline Melange & 75.33-76.07 & $11.34-12.31$ & $10.2-10.3$ & 1.0 & 0.8 \\
\hline White & $88.65-87.06$ & $9.45-11.02$ & traces & 0.9 & 0.6 \\
\hline Yolk & $49.91-50.29$ & $15.51-15.57$ & $31.9-32.3$ & 1.0 & 1.1 \\
\hline Shell & $1.61-1.63$ & $3.30-3.41$ & traces & - & 95.1 \\
\hline
\end{tabular}

Eggs contain a lot of biologically active compounds, including those which possess antimicrobial, immunomodulatory, antioxidant, anticarcinogenic, hypotensive and other properties [3-5]. 
Information on this extensive issue can be partially obtained from a number of scientific reviews publications [3-8], nevertheless it is necessary to briefly characterize the chicken egg proteins, since they constitute the most important component in the composition of the functional egg foods being developed now.

\section{Egg composition}

Egg white contains simple proteins (ovalbumen, ovoconalbumen, ovoglobulin) and complex proteins - glycoproteins or mucoproteins (ovomucoid and ovomucin) (Table 2).

The major egg white proteins are ovalbumen (54\%), ovotransferrin (12\%), ovomucoid (11\%), lysozyme (3.5\%) and ovomucin (3.5\%). Minor proteins include avidin $(0.05 \%)$, cystatin $(0.05 \%)$, ovomacroglobulin $(0.5 \%)$, ovoflavoprotein $(0.8 \%)$, ovoglycoprotein $(1.0 \%)$, and ovoinhibitor $(1.5 \%)[3,5,6]$.

\section{Biological value of the egg white}

In order to give quantitative characteristic to the quality of food protein, the parameter "biological value" (BV) in nutritional science is used. BV is the degree of food nitrogen retention in a growing body (which degree depends on the amino acid composition and other structural features of protein), and efficiency of food nitrogen utilization to maintain nitrogen balance in humans. The amino acid composition, content and ratio of essential amino acids determine the BV of a protein - the parameter that reflects the degree of protein utilization. The degree of digestion, absorption and utilization of protein is significantly influenced by food manufacture technology and methods of food processing at the food processing plants. Therefore, when evaluating $\mathrm{BV}$, its true digestibility is taken into account. The parameter "The protein digestibility-corrected amino acid score" (or PDCAAS for short) [9], which is equal to the amino acid rate multiplied by true digestibility index, has been introduced. Its highest reference value is 1.0. Comparative data on true digestibility and PDCAAS for chicken egg white and proteins obtained from various food sources are presented below in the Table 3 .

Table 2. Physical and chemical properties of egg white proteins

\begin{tabular}{|c|c|c|c|c|c|c|c|c|}
\hline Protein & $\begin{array}{c}\% \text { in } \\
\text { protein }\end{array}$ & $\mathrm{pH}$ & $\begin{array}{l}\text { Molecu-lar } \\
\text { weight }(\mathrm{kDa})\end{array}$ & $\begin{array}{l}\text { Internal } \\
\text { viscosity, } \\
100 \mathrm{~cm}^{3} / \mathrm{g}\end{array}$ & $\mathrm{T}_{\text {denaturation }}$ & $-\mathrm{SH}$ & S-S & Notes \\
\hline Ovalbumen & 54 & $4.5-4.6$ & 45000 & 0.043 & $75-84$ & 4 & 1 & Phosphoglyco-protein; 4 SH-groups \\
\hline Ovotransferrin & $12-13$ & $6.1-6.6$ & $76000-80000$ & 0.084 & $\begin{array}{c}61-65 \\
\left(76.5 ; \mathrm{Al}^{3+}\right)\end{array}$ & - & 15 & $\begin{array}{l}\text { Glycoprotein, binds to complexes } \\
\text { with iron and other metals }\end{array}$ \\
\hline Ovomucoid & 11 & $3.9-4.3$ & 28000 & 0.055 & 77 & - & 9 & Glycoprotein, trypsin inhibitor \\
\hline Ovomucin & 3.5 & $4.5-5.0$ & 110000 & 2.10 & - & - & 一 & Glycoprotein, fibrous, viscous \\
\hline Lysozyme & $3.4-3.5$ & 10.7 & $14300-14600$ & 0.027 & $69-77$ & - & 4 & $\begin{array}{l}\text { Spherical protein; } 4-\mathrm{SS}-\text { links; } \\
\text { features lytic activity }\end{array}$ \\
\hline Ovoinhibitor & 1.5 & $5.1-5.2$ & $44000-49000$ & - & - & - & - & Inhibits trypsin and chymotrypsin \\
\hline Ovoglyco-protein & 1.0 & 3.9 & $24000-24400$ & - & - & - & - & Glycoprotein \\
\hline Ovoflavoprotein & 0.8 & $4.0-4.1$ & $32000-35000$ & - & - & - & 2 & Binds riboflavin \\
\hline Ovomacro-globulin & 0.5 & $4.5-4.7$ & $760000-900000$ & 0.065 & - & - & & Glycoprotein \\
\hline Avidin & 0.5 & $9.5-10$ & $55000-68300$ & - & - & - & 1 & Binds biotin \\
\hline
\end{tabular}

Table 3. Corrected amino acid index of proteins digestibility

\begin{tabular}{|c|c|c|c|c|}
\hline Food & 胥 & 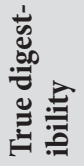 & 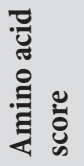 & 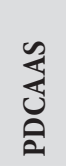 \\
\hline Casein & 94.7 & 99 & 1.19 & 1.00 \\
\hline Chicken egg white & 87 & 100 & 1.19 & 1.00 \\
\hline Beef protein & 95.2 & 98 & 0.94 & 0.92 \\
\hline Soy protein isolate & 92.2 & 98 & 0.94 & 0.92 \\
\hline
\end{tabular}

\section{Gel-forming properties of chicken egg}

Currently the share of eggs and their separate components in formulations of a wide range of foods is increasing steadily, which is explained by their properties: emulsifying ability and thermal gelation (coagulation) [7].

Foaming capacity of egg white proteins

Poultry egg white is an aqueous protein solution with $84-89 \%$ of water. It also contains minor amounts of carbohydrates, vitamins and minerals. Proteins, which make up more than $90 \%$ of the egg white dry matter, are heat-sensitive and prone to surface denaturation, which explains their unique technological properties. As it's known, foams are the dispersed systems consisting of many gas bubbles separated by thin (only single colloidal particle thick) films of liquid. Adding of surfactants, which reduce surface tension, contribute to foaming. However, stable foaming requires the presence of high-molecular compounds in the system, for example, proteins which form two-sided strong adsorption layers on the surface of thin films of liquid. Egg white proteins are amphiphilic and feature relatively high surface hydrophobic properties; therefore, they diffuse towards the air-water phase interfaces, where they are adsorbed effectively. This flexibility of molecules allows proteins to rearrange their conformational structure at the interface, which leads to significant decrease in the superficial tension at these interfaces. The ability of proteins to form stable intermolecular structures, especially partially denatured proteins, allows them forming viscoelastic superficial films that ensure foam stability. The high foaming capacity of chicken egg protein macromolecules is directly 
related to their interfacial properties, i. e. the ability to form interfacial layers at the liquid-gas interface. The foaming properties of various proteins of chicken egg white are not equal, and therefore they contribute to the formation of its foaming properties in various extents (Table 4).

Table 4. Interfacial characteristics of the major proteins of egg white [8]

\begin{tabular}{|l|c|c|}
\hline \multicolumn{1}{|c|}{ Protein } & $\begin{array}{c}\text { Superficial } \\
\text { tension } \\
(\mathrm{mN} / \mathrm{m})\end{array}$ & $\begin{array}{c}\text { Foaming } \\
\text { coefficient } \\
\left(\mathrm{cm}^{3} / \mathbf{g} \text { per }\right. \\
\text { minute })\end{array}$ \\
\hline Ovalbumen & 51.8 & 0.59 \\
\hline Ovotransferrin & 42.4 & 0.34 \\
\hline Lysozyme & 42 & 0.12 \\
\hline Ovomucoid & 39 & 0 \\
\hline Ovomucin & No data & 0 \\
\hline $\begin{array}{l}\text { Mixture of these proteins in the same } \\
\text { proportion as in egg white }\end{array}$ & 46.7 & 3.08 \\
\hline
\end{tabular}

Egg white is considered to be reference model for foaming properties, which other animal and plant proteins are compared to [10-15]. Despite numerous comparative studies of the properties of some individual egg white proteins and attempts to rank them according to these properties [10,16,17], it is almost impossible because of complexity of egg white proteins composition and potentially possible synergistic interactions of individual proteins. All those complexities make it almost impossible to identify the special role of each individual protein in the foaming process [18]. It is very difficult to predict the foaming properties of any mixture of proteins, since individual proteins may compete among themselves for the surface, or they may substitute each other at the interface [19]. However, the foaming capacities of individual proteins isolated from egg white are always less than the foaming capacity of egg white as a whole. Egg white foams are the main component of such foods as meringues, nougat and light biscuits. Another peculiar feature of egg white-based foams is the dependence of their characteristics on quality of the original egg white [20]. Since the foaming properties of dense egg white and liquid egg white differ from each other [21], all factors affecting the ratio of these fractions in the egg white (i. e. shelf life of the egg, age and breed of laying hen) also affect the foaming capacity of the egg white [22-26]. Another extremely important parameter is the accuracy of separation of egg white and yolk, since even very small amounts of yolk $(0.022 \%)$ in the egg white significantly reduce its foaming capacity [27]. Heat treatment also reduces the foaming capacity of the egg white. Industrial pasteurization can reduce by $10 \%$ both the foaming capacity of the egg white and the foam stability as well $[20,28,29]$. The dripping of liquid phase from the foam can be increased threefold after its pasteurization. Heating the protein during drying also worsens the foaming properties of the egg white, and the foaming may be decreased by 10 to $60 \%$ due to $\mathrm{pH}$ of the egg white during drying, and may decrease the foam stability by $20 \%$.

\section{Gelation properties of egg white}

The process of egg proteins gelation is described in details by the model of thermal gelation of globular structure proteins [5]. In this model gelation is considered as a two-stage process, sequentially including denaturation and aggregation. The scheme is as follows: native protein $\rightarrow$ denatured protein (long chains) $\rightarrow$ aggregated protein (associated mesh).

Denaturation results in very important changes in proteins properties. First of all, they lose their ability to hydrate, the aqueous protective shell around the globules disappears, they join together, grow larger and lose their solubility. This process is called coagulation.

When eggs are heated, the proteins that make up their composition, changes first. Due to the thermal denaturation of protein substances at $50-55^{\circ} \mathrm{C}$, local opacities are formed in the transparent mass, and gradually spread out. At $65^{\circ} \mathrm{C}$ the entire mass of protein get thicker, and at $75^{\circ} \mathrm{C}$ it turns into a solid opaque mass of a very delicate consistency. At $80^{\circ} \mathrm{C}$ the gel is obtained which is able to keep its shape, and along with further heating (above $85^{\circ} \mathrm{C}$ ) it becomes more and more dense. The degree of compaction of the protein gel depends on heating duration. Chicken egg white has 2 main endothermic points at $60-65^{\circ} \mathrm{C}$ and $80-85^{\circ} \mathrm{C}$, which corresponds to the temperatures of ovotransferrin and ovalbumen denaturation [30,31].

Differences in opacity of samples with different salt content are associated with differences in protein clots sizes and rate of protein aggregation. Salt $\mathrm{NaCl}$ causes changes in conformation of egg proteins proportionally to increase in the ionic strength of the solution. Increasing the solubility of protein molecules increases their susceptibility to thermal denaturation. The high content of $\mathrm{NaCl}$ leads to coagulation of protein, thus playing a decisive role in the process of its aggregation.

At the first stage of gelation the "folded" macromolecules of globular proteins "unfold", thus forming the denatured proteins, and release their hydrophobic "internal" structure. At the second stage of gelation (aggregation), macromolecules of denatured proteins interact with each other to form even higher molecular weight aggregates, which in its turn also interact with each other, which ultimately leads to the formation of three-dimensional gel structure [32]. Comparison of the denaturation rate with the aggregation rate helps determine the characteristics of the obtained gel. The wide range of factors affect protein aggregation, which is important because changing the aggregation rate in relation to the denaturation rate affects the characteristics of the obtained gel. Some of these factors are listed below.

Electrostatic charge $(\mathrm{pH})$ can alter the charge distribution among the side chains of amino acids and, accordingly, either decrease or increase protein-protein interactions. The main factor in heat-induced aggregation of ovalbumen $(\mathrm{pH} 4.5-4.6)$ is the degree of electrostatic repulsion between the protein molecules of exposed denaturation. The aggregation rate of a heated $1.8 \%$ ovalbumen solution 
is higher at $\mathrm{pH}=5.5$ and 8.5 than at $\mathrm{pH}=7.0$. At a $\mathrm{pH}$ of 5.5 the opacity builds up more rapidly.

The concentration of protein in solution also affects aggregation rate. The high concentration of protein causes the molecules to come closer together to form aggregates at lower temperatures.

The $\mathrm{pH}$ value required for achieving the same opacity that indicates protein aggregation, increases as the protein concentration increases, and the $\mathrm{pH}$ shifts to alkaline direction from the isoelectric point from 6 to 11, and decreases when the $\mathrm{pH}$ shifts to acidic direction from 4.5 to 3.0. There is an assumption [5] that the denaturation rate causes a low rate of aggregation, because the forces of attraction between denatured protein chains are low. The resulting gel will have a fine mesh of protein chains, will be more transparent, and will be characterized by less syneresis than the gel obtained at the high aggregation rate. A larger mesh of protein chains will result to the opaque gel with large internodes capable of retaining a solvent that is easily pressed out from the matrix. Conditions that favor denaturation, such as high or low $\mathrm{pH}$, reduce aggregation of globular proteins. In this case, due to the high charge of the molecules, denaturation based on protein-solvent interactions prevails rather than aggregation caused by protein-protein interactions. A gel mesh with a certain degree of structural regularity can be obtained if the aggregation pace is slower than the denaturation pace - this slower rate "gives time" for denatured molecules to self-orientate before aggregation, thus reducing opacity and increasing elasticity compared to conditions under which aggregation rate is not retarded. If aggregation occurs simultaneously with denaturation, then opaque and less elastic gels are formed.

The efficiency and rate of both stages - i. e. the deployment of molecules and their aggregation - depend on the concentration of the protein, the ionic strength of the solution, the $\mathrm{pH}$ value, and other parameters that can affect the number and nature of intermolecular and intramolecular interactions that affect the rheological properties of the resulting gel. For example, in the gels obtained by thermal processing of egg contents, these interactions were predominantly hydrophobic and electrostatic, but in these systems the higher-energy interactions were also found (for example, interactions caused by disulfide bridges); thiol and amino groups are highly reactive, especially in alkaline media. It has been found that sugars protect proteins from heat, but create coarser aggregates, and worsen the rheological properties of the resulting gel [32]. If standard conditions of industrial pasteurization of the protein do not affect its gelation properties, then drying the protein can be detrimental to the gelation. This adverse effect can be prevented by adjusting the $\mathrm{pH}$ of the egg white before drying it. At the same time the research [30] recommends $\mathrm{pH} 8.5$, while in the article [33] the best gel stability was obtained at $\mathrm{pH} 6.5$.

\section{Egg white gels}

In the process of developing of egg foods technologies, the gelation capacity of eggs has great importance.
Gelation is an ordered aggregation of proteins, which may or may not be denatured, to form a three-dimensional mesh, which mesh can form a well-ordered matrix. The gelation properties of egg white are determined by the included proteins. In general, gelation is associated with an imbalance between mutually attractive (van der Waals) and mutually repulsive (electrostatic, steric) interactions that determine the spatial structure of the protein in solution. The protein structure can be modified in various ways. Examples of the modification are given in the monograph by V. N. Izmailova and P. A. Rebinder "Structure formation in protein systems" and by other authors [34]. Both during acidification and alkalization the native globular proteins can irreversibly "rearrange" into proteins of the fibrillar type. The formation of thixotropic ovalbumen gels due to addition of acetic acid may result from formation of hydrogen bonds between acetic acid and protein. Ovalbumen gets denaturated in presence of urea and alkali, when this protein forms the gel. Alkaline ovalbumen gels melt the faster, the higher is $\mathrm{pH}$ of the gel. Ovalbumen gels can also be prepared at high pressures which cause denaturation changes in protein macromolecules.

The results of heat treatment research are of particular interest, as the heat treatment is widely used in the food industry for formation of gels from egg white and yolk. In aqueous solutions of ovalbumen at room temperature "the induction period of structure formation got shorter with increasing protein concentration". At the same time, the strength of the gel structure increased due to an increase in the number of intermolecular contacts per volume unit, accompanied by conformational changes in protein macromolecules. The process of denaturation of ovalbumen, exposed to acid or alkali, was accelerated by heating. While discussing the nature of the interactions that determine the strength of the resulting ovalbumen gels, the authors come to the conclusion that it is determined by hydrogen bonds and hydrophobic interactions. In this case electrostatic interactions are excluded due to the formation of the gel structure in strongly acidic and strongly alkaline media. Thus, the structure of ovalbumen gels is similar to thixotropic coagulation structural meshes, where the particles of the dispersed phase or macromolecules aggregates are bound together by van der Waals forces which occur between hydrocarbon hydrophobic amino acid residues of ovalbumen macromolecules during protein denaturation.

The type and force of interaction between denatured protein molecules depend on their structure and, in particular, on the "extent of unfolding" of protein molecules at the end of the denaturation stage. These interactions also depend on the general physical and chemical conditions in the system, which can both restrict and contribute to gelation, i. e. respectively increase or decrease the level of aggregation and, conversely, decrease or increase the degree of denaturation, after which these interactions begin [35]. These mechanisms were intensively researched on the samples of thermally induced gelation of egg white and ovalbumen, while the pecu- 
liar attention was paid to the influence of the ionic strength of a solution on the structure and characteristics of the resulting gels [32, 36-39]. When heated at high ionic strength, ions shield the charges of protein molecules, which process promotes hydrophobic interactions [40]. In these conditions aggregates of partially denatured proteins are formed at random. These aggregates create cloudy opaque gels with low rates of rigidity [hardness], low elasticity and poor waterholding capacity (WHC). On the other hand, at low ionic strength the higher electrostatic repulsive forces slow down the aggregation process [32] and promote protein denaturation. Finally, the further process of aggregation includes the interaction of hydrophobic sections of molecules with the formation of linear polymer aggregates. In media with the higher ionic strength these aggregates can interact to form gels with good processing properties.

The thermal gelation capacity has been used to develop technologies and new types of functional egg foods, as well as meat foods with a high share of eggs included in their composition.

Another important parameter to monitor the quality of protein gelation is the $\mathrm{pH}$ value. Close to their isoelectric point $(\mathrm{pH} \sim 5)$ the proteins are more prone to the formation of randomly arranged aggregates, similar to those obtained at high ionic force. On the contrary the gelation properties of protein are expressed in the best way within the alkaline $\mathrm{pH}$ range [41,42]. On the other hand at low $\mathrm{pH}(2.0)$ the gelation temperature decreases and the rheological properties of the gel worsen, which is explained by decrease in protein solubility [32]. The composition of the albumen fraction in chicken egg whites also affects their aggregation. The denaturation temperature of conalbumen, globulin, ovalbumen and lysozyme is $57.3^{\circ} \mathrm{C} ; 72.0^{\circ} \mathrm{C}$; $71.5^{\circ} \mathrm{C}$ and $81.5^{\circ} \mathrm{C}$, respectively, ovomucin and ovomucoid do not coagulate at these temperatures. The lysozymebased gel is the strongest gel, the globulin-based gel is less strong. Conalbumen gels feature the greatest drainage rate. In binary mixtures of the albumen fraction of chicken egg whites, the mixtures get aggregated close to the denaturation temperature of the least thermostable protein. The lysozyme-globulin gel is the strongest, while the ovomucoid-ovalbumen gel features the least strength [43].

\section{Egg white coagulation}

Accidental aggregation of already denatured protein molecules, when polymer-polymer interactions dominate over polymer-solvent interactions, leads to protein coagulation.

Coagulation is the process of particles adhesion that leads to formation of large aggregates. As a result of coagulation the system loses its sedimentation stability. There are two stages of coagulation. The first of these is the latent coagulation. At this stage the particles grow larger, but still keep their sedimentation stability. The formation of disulfide bonds and their impact on hydrophobic amino acid residues are involved in the first stage of coagulation. Proteins with a higher percentage of hydrophobic amino acids are classified as the proteins of coagulating type, while proteins with a lower percentage of hydrophobic amino acids are the proteins of gelation type. Further heating causes the egg albumen to polymerize and form a mesh. Many globular proteins with different sulphydryl groups can form thermally induced gels.

The second stage is the evident coagulation. At this stage the particles lose their sedimentation stability. If the density of the particles is higher than the density of the dispersion medium, those particles fall out. Coagulation can be caused by various factors: heat, high pressure, presence of salts, alkalis, acids, alcohols and denaturing agents, e. g. urea. In cooking conditions, the egg white coagulates at a temperature of $57-60^{\circ} \mathrm{C}$, while the yolk or whole egg coagulates at slightly higher temperature $\left(65-70^{\circ} \mathrm{C}\right)$. Adding of certain organic acids or cooking salt can raise the upper threshold of the protein thermal coagulation, which mechanism is used for eggs pasteurization $[30,31,43,44]$.

\section{Changes in the functional parameters of egg white in relation to the heating temperature}

During coagulation and aggregation of proteins the disulfide bonds are redistributed, the content of Sh-groups changes, which leads to $\mathrm{pH}$ change. Thus, $\mathrm{pH}$ is a parameter that characterizes the changes in protein denaturation process - coagulation and aggregation.

The research conducted by Stefanova I. L. et al. [45] shows (Figure 1) that while heating the egg white with citric acid and cooking salt, the $\mathrm{pH}$ of the protein changes as follows:

- it decreases till the temperature of $65^{\circ} \mathrm{C}$;

- then it gradually grows up to the original value till the temperature of $(75-80)^{\circ} \mathrm{C}$;

- at the temperature of $82^{\circ} \mathrm{C} \mathrm{pH}$ increases sharply and grows up from 7.2-7.4 units to 8.6 units at the temperature of $92^{\circ} \mathrm{C}$.

These data prove that protein coagulation occurs at a temperature of $(82 \pm 2)^{\circ} \mathrm{C}$. At the temperatures above $82^{\circ} \mathrm{C}$ the egg white clot keeps thickening at temperatures up to $88^{\circ} \mathrm{C}$.

When the egg white is heated to the temperature of $80^{\circ} \mathrm{C}$, the coagulated protein forms a suspension that slightly compacts, but does not separate from the whey while centrifuging at $3,500 \mathrm{rpm}$. With a further increase in temperature a clot is formed, the amount of which increase along with the increase of temperature up to $86-88^{\circ} \mathrm{C}$. Then the mass of the clot does not change; only further compaction of the clot occurs.

\section{Composition and yield of coagulated protein depending on the level of egg white heating}

The level of heating directly affects the yield and protein composition (Figure 2). The separation of the clot begins at $82^{\circ} \mathrm{C}$. At the temperatures up to $84^{\circ} \mathrm{C}$, the yield of coagulated egg white increases by more than $15 \%$. At $88^{\circ} \mathrm{C}$ the yield is the highest. A further increase of temperature leads to a slight decrease in yield of protein.

The temperature of denaturation transitions depends on adding of acids, alkalis and salts to protein solutions [45]. 


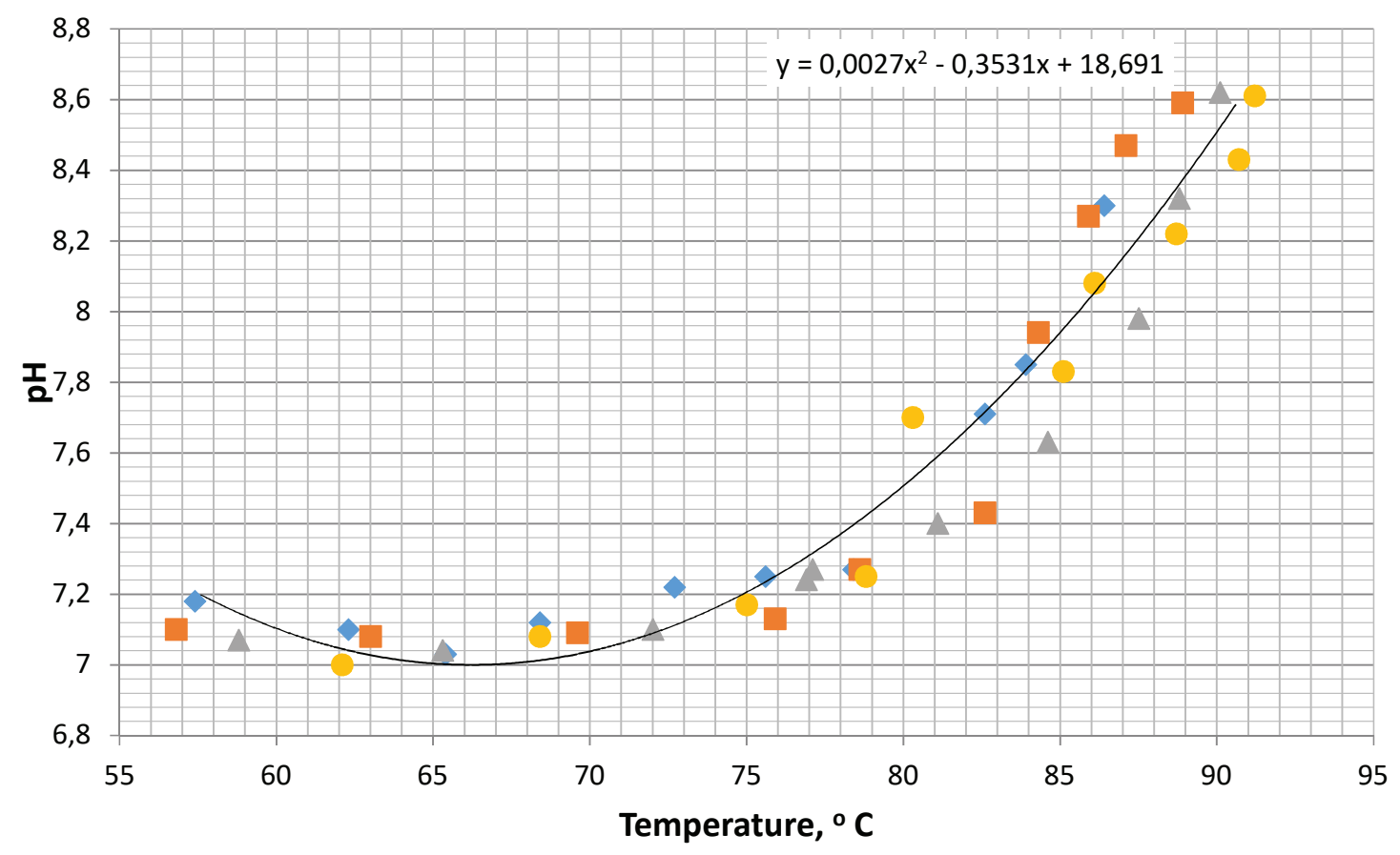

Figure 1. Changes of egg white clot $\mathrm{pH}$ during heating

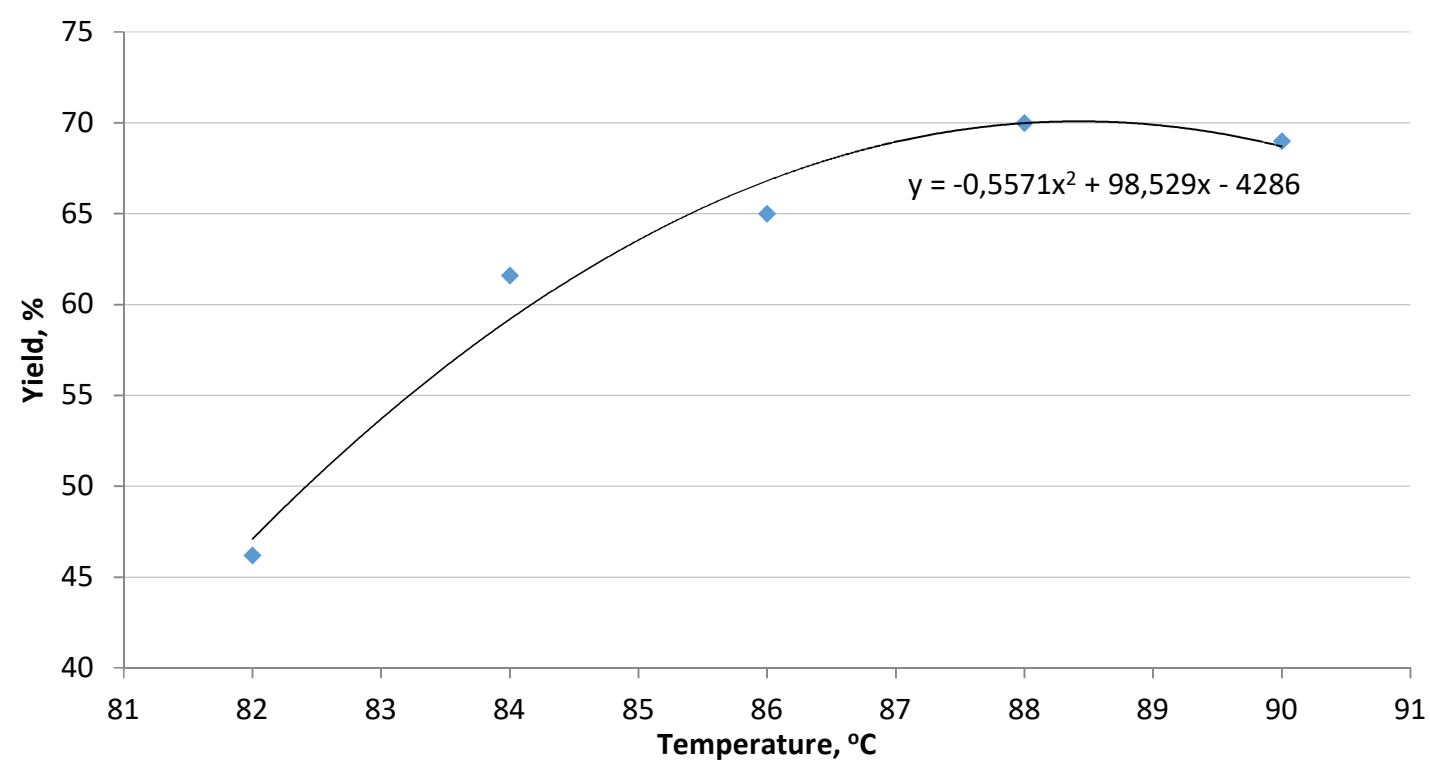

Figure 2. Dependence of coagulated protein yield on temperature of the protein mixture heating

It is shown in the research [45] that while raising the amount of added citric acid from 0.10 to $0.13 \%$ simultaneously with heating up to a temperature of $86^{\circ} \mathrm{C}$, the yield of protein increases from 61 to $66 \%$ and decreases with a further buildup of acid concentration (Figure 3). The dependence of protein yield on amount of the introduced acid when the mixture is heated to a temperature of $88^{\circ} \mathrm{C}$ has the same pattern, but the yield is higher. The highest yield is observed at $86^{\circ} \mathrm{C}$ and $88^{\circ} \mathrm{C}$, and it accounts for $66.2 \%$ and $68.5 \%$, respectively. Thus, the optimal citric acid concentration is $0.13 \%$.

When the temperature of the final heating raises up to $88^{\circ} \mathrm{C}$, the yield of coagulated protein increases while the amount of drained whey decreases. The composition of the coagulated protein changes (Table 5). It was found when coagulation temperature increases and, accordingly, the yield, the content of protein and dry matter in the coagulated egg white (clot) increases, while $92.65 \%$ of the protein remains in the coagulated protein, and only $7.35 \%$ of the protein remains in the whey. The dry matter in the coagulated egg white accounts for $85.3 \%$ of dry matter in the original egg white.

Table 5. Content of protein and dry matter in coagulated egg white

\begin{tabular}{|c|c|c|c|c|}
\hline $\begin{array}{c}\text { No. of } \\
\text { test }\end{array}$ & $\begin{array}{c}\text { Tempera- } \\
\text { ture, }{ }^{\circ} \mathrm{C}\end{array}$ & Yield, \% & $\begin{array}{c}\text { Mass fraction } \\
\text { of protein, \% }\end{array}$ & $\begin{array}{c}\text { Mass fraction } \\
\text { of dry matter, \% }\end{array}$ \\
\hline 1 & 82 & 46.4 & $14.8 \pm 0.5$ & $17.89 \pm 0.35$ \\
\hline 2 & 84 & 61.6 & $13.8 \pm 0.3$ & $16.73 \pm 0.33$ \\
\hline 3 & 86 & 65.0 & $14.1 \pm 0.5$ & $17.25 \pm 0.28$ \\
\hline 5 & 88 & 70.0 & $14.1 \pm 0.4$ & $17.30 \pm 0.28$ \\
\hline 5 & 90 & 69.0 & $14.2 \pm 0.4$ & $17.41 \pm 0.30$ \\
\hline
\end{tabular}

Note: mass fraction of protein in the original egg white $-10.6 \pm 0.3 \%$, mass fraction of dry matter $-12.86 \pm 0.26 \%$ 


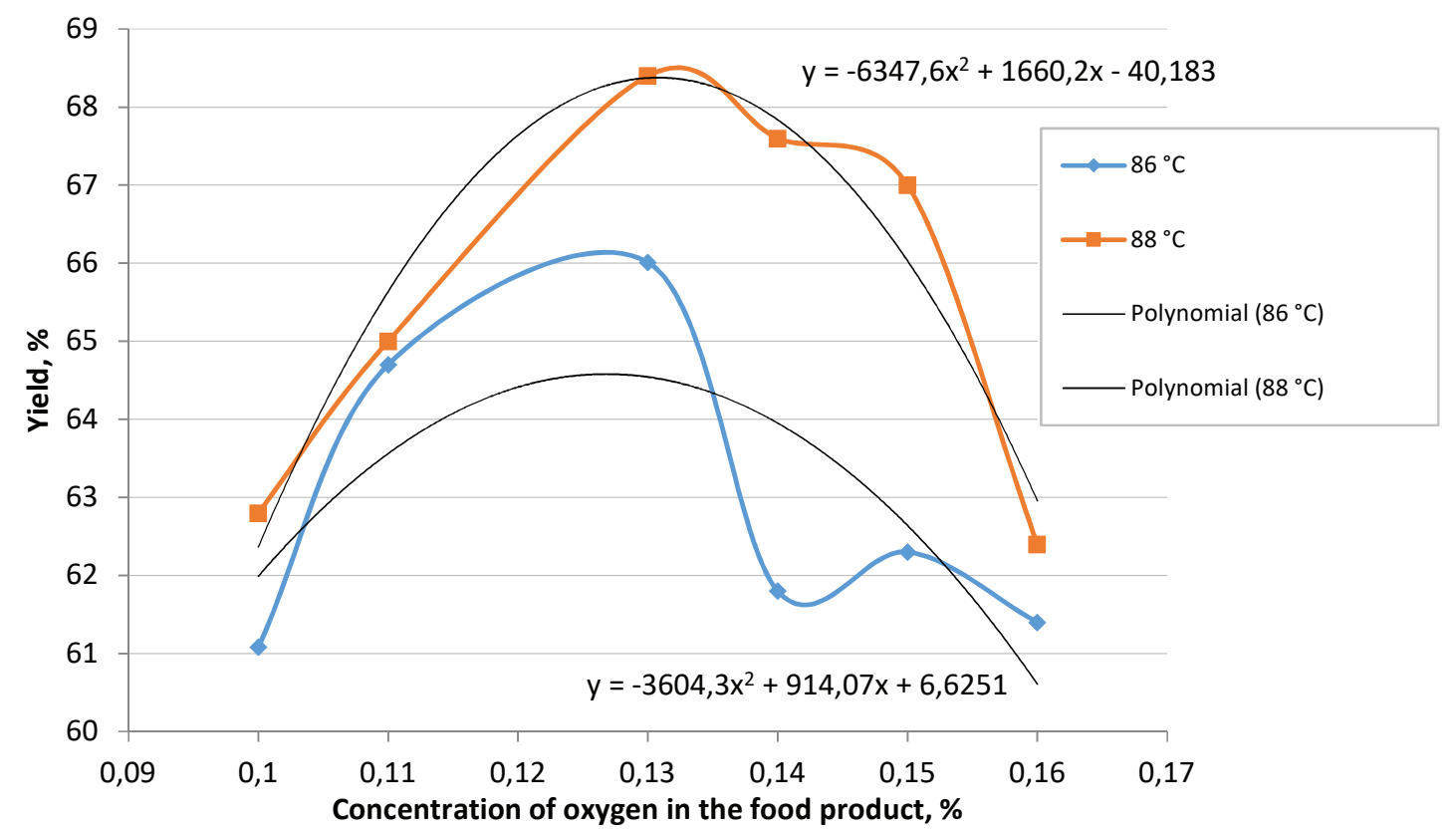

Figure 3. Dependence of coagulated protein yield on amount of added acid at different levels of heating

Table 6. Mineral composition of coagulated protein

\begin{tabular}{|c|c|c|c|c|c|c|}
\hline \multirow{2}{*}{ Product } & \multicolumn{4}{|c}{$\mu \mathrm{g} / \mathrm{kg}$} & \multicolumn{2}{c|}{$\mu \mathrm{g} / 100 \mathrm{~g}$} \\
\hline Coagulated clot & $\mathrm{Ca}$ & $\mathrm{Mg}$ & $\mathrm{K}$ & $\mathrm{Na}$ & $\mathrm{Fe}$ & $\mathbf{P}$ \\
\hline
\end{tabular}

Mineral composition of the coagulated protein is represented by the elements like sodium, potassium, calcium, iron, magnesium, phosphorus, chlorine, etc. and is shown below in the Table 6 .

In conclusion, we also provide data on change in the total chemical composition of eggs, depending on the mode of heat treatment (Table 7).

Table 7. The content of protein and fat in the egg, depending on the heat treatment mode

\begin{tabular}{|l|c|c|c|}
\hline \multicolumn{1}{|c|}{ Egg $(\mathbf{5 0} \mathbf{g})$} & Protein $(\mathrm{g})$ & Calories & Fat $(\mathrm{g})$ \\
\hline Raw egg & 6.3 & 72 & 4.7 \\
\hline Hardboiled egg & 6.3 & 78 & 5.3 \\
\hline Scrambled eggs & 5.0 & 75 & 5.5 \\
\hline Poached egg & 6.2 & 69 & 4.7 \\
\hline Omelet & 5.3 & 77 & 5.8 \\
\hline Coagulated egg white & 7.5 & 30 & - \\
\hline Coagulated melange & 7.4 & 87 & 6.4 \\
\hline
\end{tabular}

Coagulation of egg white can significantly affect its allergenic potency. Egg allergy is based on the allergy for the egg white. Sensitization to the protein components of chicken eggs is often accompanied with an allergy for the yolk and eggs of some other poultry species. Among young children the allergy for egg white is the second most common food allergy after allergy for cow's milk protein [44]. The overall prevalence of allergy for chicken egg white among the children in European countries is about 2.5\% [46]. Reducing the allergenic potency of food proteins is an important problem for food technology, which faces the challenge of manufacturing of specialized hypoallergenic foods. Although food proteins are denatured in result of heat treatment, no decrease in their allergenic potency in the general case can be guaranteed, since the allergenic sectors of the protein in some cases are short fragments of the polypeptide sequence which are resistant to denaturation. Nevertheless, the literature contains data on decrease in the allergenic potencies and properties of food proteins during intense heating and cooking [47].

It may be possibly explained that the denatured food antigens are more actively attacked by digestive proteases in comparison with intact protein and, therefore, the absorption of their antigenic structures is reduced. Heat treatment destroys the conformational epitopes of egg whites, which cause the immune system of an allergic predisposed person to form IgE antibodies. A brief description of the potential allergenic properties of a range of chicken egg whites is presented in the research [48]. The authors note the complexity of the antigenic composition of the raw chicken egg white, and also state that 13 egg proteins have allergenic properties and ovalbumen (OVA) and ovomucoid (OVM) are allergenic to the greatest extent. As noted, OVA is phosphoprotein with MW of $44 \mathrm{kDa}$. Protein is relatively poorly attacked by proteases and can be absorbed in the digestive tract in an undigested form. OVA is one of the most important food allergens. The protein is thermolabile (it easily denatures when heated to form an insoluble gel), but its allergenic potency decreases slightly. The antigenic determinants of OVA, which are recognized by antibodies of the IgE class, appear to be consequent [49]. OVM, due to its high resistance to proteases of the human gastrointestinal tract, quite easily penetrates the intestinal barrier and causes allergic sensitization. The antigenic structures of OVM are thermolabile, and the allergenic potency of this protein decreases sharply when heated. This is apparently 
facilitated by the discovery that the allergenic epitopes of OVM are conformational, in contrast to OVA which are not. The promising use of thermally induced coagulation of egg white and / or chicken egg melange to reduce the allergenic potency of the resulting food is evidenced by the data that quite often people who are allergic to chicken egg whites are able to tolerate them when egg whites are heattreated [50].

It was shown in the research [51] that thermal coagulation of egg white acidified with citric acid provides a 15fold decrease in the original antigenicity in comparison with native egg white (Figure 4). The content of intact ovalbumen, the antigenicity of which is taken as $100 \%$, is $2.2 \%$ and $33 \%$ respectively in the coagulated and original lyophilized egg white. The obtained results prove a decrease in the potential allergenic properties of coagulated egg white and are an important additional argument for the prospects of using the egg whites in the composition of mass market foods and in specialized foods also [52,53].

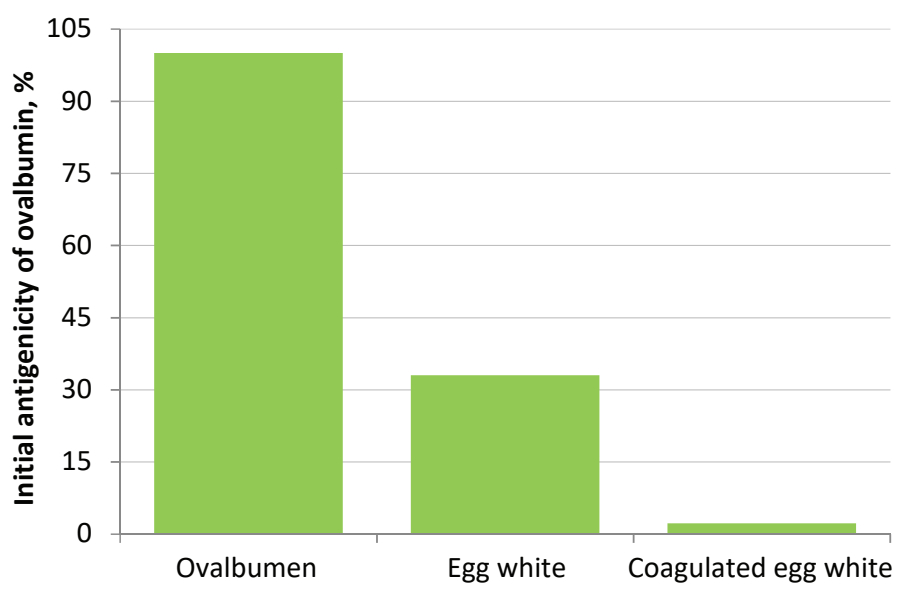

Figure 4. Antigenicity of coagulated egg white

A wide range of coagulated egg foods has been developed on the basis of coagulated egg whites [53].

The coagulation process provides for fortification of chicken eggs with minor compounds. Stefanova I. L. et al. in their research [54] proved that fortification of protein in the coagulation process with iodine and calcium provides $25-30 \%$ of the daily demand for calcium and iodine.

The content of calcium in the coagulated protein, depending on the level of its heating during egg white coagulation (i. e. adding of a mineral fortifier in amount of $1 \%$ of the egg white mass during fortification of egg white with calcium and iodine) decreases together with rising of coagulation temperature from $84^{\circ} \mathrm{C}$ to $90^{\circ} \mathrm{C}$, and calcium content amounts to $551.98 ; 518.95 ; 470.86$ and $439.00 \mathrm{mg} / 100 \mathrm{~g}$ protein, respectively (Figure 5 ). When the temperature rises from $84^{\circ} \mathrm{C}$ to $90^{\circ} \mathrm{C}$, calcium is lost at level 25.2, 28.4, $35.0,39.4 \%$. Basically, calcium losses occur due to its excretion with whey.

The content of calcium in the fortified melange (Figure 5) at the introduction of calcium at dose of $725 \mathrm{mg} / 100 \mathrm{~g}$ of melange is $425.4 ; 392.4 ; 399.4$ and $396.2 \mathrm{mg} / 100 \mathrm{~g}$ within the range of temperatures of $86^{\circ} \mathrm{C} ; 88^{\circ} \mathrm{C} ; 90^{\circ} \mathrm{C} ; 92^{\circ} \mathrm{C}$, re- spectively, and it practically does not change within the temperature range $88-92^{\circ} \mathrm{C}$. Calcium losses are $44.9-45.9 \%$. Melange binds $54.1-55.1 \%$ of the added calcium.

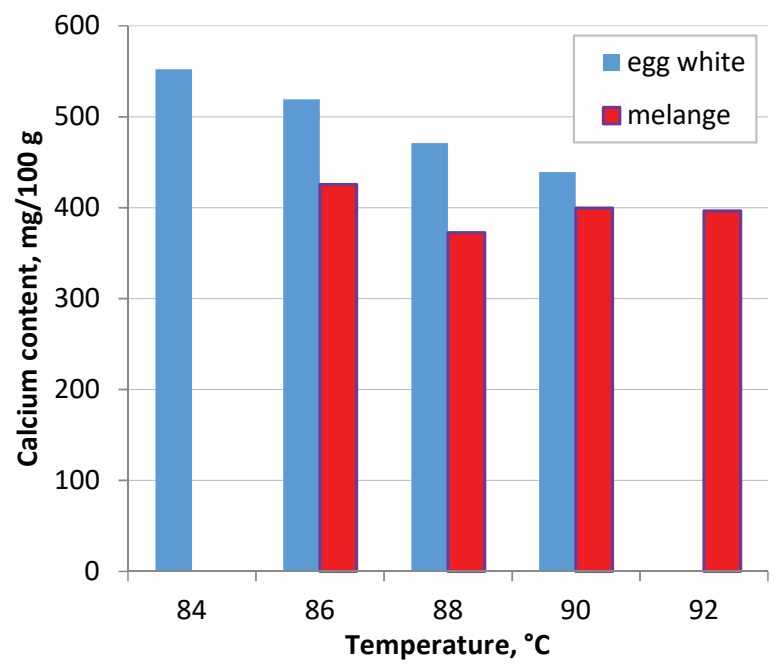

Figure 5. Change of calcium content in coagulated egg white and melange depending on the level of heating

Egg white binds more calcium: $60.6-65.0 \%$ versus $54.1-$ $55.1 \%$ bound by melange, despite more considerable whey drainage $\left(23.2 \%\right.$ for egg white at $88^{\circ} \mathrm{C}$ versus $9.2 \%$ for melange at $\left.90^{\circ} \mathrm{C}\right)$.

The content of iodine in the coagulated protein, depending on the temperature of final coagulation $\left(86^{\circ} \mathrm{C}\right.$; $88^{\circ} \mathrm{C} ; 90^{\circ} \mathrm{C} ; 92^{\circ} \mathrm{C}$ ), showed that when fortifying the protein with seaweed powder containing $456 \mu \mathrm{g}$ of iodine per $100 \mathrm{~g}$ of egg white, the mass fraction of iodine is respectively $298 ; 253 ; 311$ and $281 \mu \mathrm{g} / 100 \mathrm{~g}$ of coagulated egg white, iodine losses are $34.6 ; 44.5 ; 31.8$ and $38.4 \%$, respectively. The loss of iodine during egg whites fortification during the coagulation process is lower than when iodine is added at the moment of the food formulation. When the melange is fortified with seaweed powder in amount of $0.2 \%$, the mass fraction of iodine in the coagulated melange is 0.203 ; $0.243 ; 0.258 ; 0.273 \mu \mathrm{g} / 100 \mathrm{~g}$ respectively, depending on the heating temperature $\left(86^{\circ} \mathrm{C} ; 88^{\circ} \mathrm{C} ; 90^{\circ} \mathrm{C} ; 92^{\circ} \mathrm{C}\right)$. The share of iodine bound with melange is lower in comparison with egg white fortification with iodine, which is apparently related to the lower protein content in melange. (Figure 6).

The high frequency of metabolic syndromes, type 2 diabetes mellitus and concomitant clinical complications determine the relevance of development and creation of a wide range of new functional foods for their use in the diet of people with disorders of carbohydrate and / or fat metabolism. The results of clinical and experimental studies, so far accumulated by world nutritional science, prove the hypolipidemic and hypocholesterolaemic effects of a wide range of polyphenolic compounds.

The authors of the research [55] implemented a significant comprehensive work for development of functional specialized foods based on the egg whites fortified with cranberry polyphenolic compounds. The sorption of anthocyanins by the chicken eggs whites in the process of hydrolysis occurs to the greatest extent when the egg white is 
A

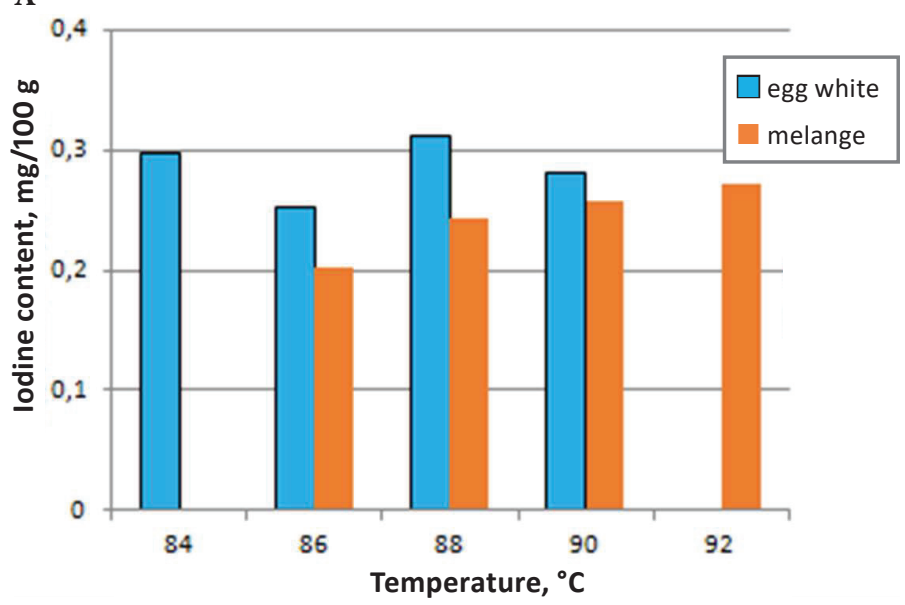

B

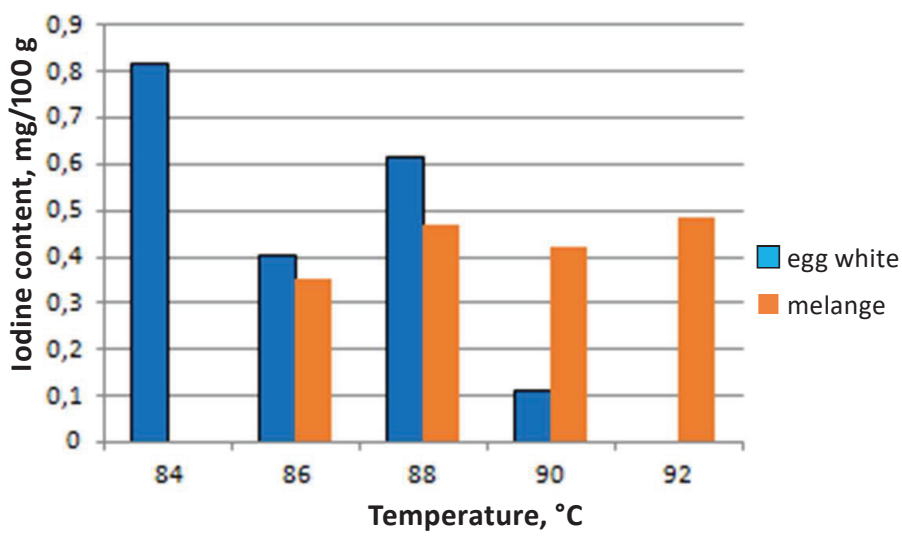

Figure 6. Change in the content of iodine in coagulated egg white and melange, depending on the heating level, with addition of $0.2 \%$ seaweed powder (A) and $0.5 \%$ seaweed powder (B)

heated to $82 \pm 1{ }^{\circ} \mathrm{C}$. In this case the yield of the functional food ingredient (FFI) is $70.6-74.0 \%$ (Table 8). The anthocyanin profile is represented mainly by cyanidin-3-galactoside, peonidin-3-glalactoside (Table 9).

It is possible to substitute poultry meat with coagulated egg products (egg white, yolk and melange) in amount of
$15-25$ in the production of semi-finished foods\%, which led to creation of whole range of foods with high biological value and low fat content [56-58].

Table 8. Anthocyanin content in FFI depending on the coagulation temperature

\begin{tabular}{|c|c|c|c|c|c|}
$\begin{array}{c}\text { Temperature } \\
\text { of coagulation, }{ }^{\circ} \mathrm{C}\end{array}$ & $\begin{array}{c}100 \% \\
\text { juice }\end{array}$ & 80 & 82 & 84 & 86 \\
\hline $\begin{array}{l}\text { The amount of anthocyanins, } \\
(\mathbf{m g} / \mathbf{1 0 0} \mathrm{g} \mathrm{B})^{\star}\end{array}$ & 17.56 & 3.14 & 3.79 & 2.97 & 1.96 \\
\hline${ }^{*}$ Content in the solid food & & & & & \\
\hline
\end{tabular}

Table 9. Anthocyanin profile in FFI depending on the coagulation temperature

\begin{tabular}{|l|c|c|c|c|c|c|}
\hline \multirow{2}{*}{ Anthocyanin } & \multicolumn{4}{|c|}{ Content, \% of anthocyanin amount } \\
\hline & $100 \%$ juice & $\mathrm{B80}^{\circ} \mathrm{C}$ & $\mathrm{B82}{ }^{\circ} \mathrm{C}$ & $\mathrm{B}^{\circ}{ }^{\circ} \mathrm{C}$ & $\mathbf{B 8 6}{ }^{\circ} \mathrm{C}$ \\
\hline Cyanidin-3-galactoside & 28.2 & 21.1 & 21.8 & 21.8 & 19.1 \\
\hline Cyanidin-3-glucoside & 3.0 & 1.9 & 2.0 & 1.9 & 3.1 \\
\hline Cyanidin-3-arabinoside & 19.0 & 18.7 & 19.6 & 19.1 & 17.1 \\
\hline Peonidin-3-galactoside & 31.4 & 35.2 & 34.1 & 34.6 & 36.3 \\
\hline Peonidin-3-glucoside & 5.5 & 6.8 & 6.5 & 6.7 & 7.4 \\
\hline Peonidin-3-arabinoside & 12.9 & 16.3 & 16.0 & 15.9 & 17.0 \\
\hline Malvidin-3-arabinoside & traces & traces & traces & traces & traces \\
\hline
\end{tabular}

\section{Conclusions}

Eggs are not only the unique mono food necessary in human nutrition. Eggs contain egg whites of a high biological value and biologically significant macro- and micronutrients. Egg whites are also a multifunctional raw material component for development and creation of new modern foods for various aims and tasks. The study of the functional and technological properties of a whole egg and its components, the influence of various parameters of technological processes on the physical and chemical properties of an egg, and ability to preserve the biologically significant key characteristics allows creating a wide range of healthy foods.

\section{REFERENCES}

1. Miranda, J. M., Anton, X., Redondo-Valbuena, C., Roca-Saavedra, P., Rodriguez, J. A., Lamas, A. et al. (2015). Egg and egg-derived foods: Effects on human health and use as functional foods. Nutrients, 7(1), 706-729. https://doi.org/10.3390/nu7010706 2. Guchin, V.V., Stefanova, I.L., Klimenkova, A. Yu. (2015). The development of new foods from egg white. Poultry and poultry products, 2, 22-24 (In Russian)

3. 3.Gossett, P.W., Rizvi, S.S.H., Baker, R.C. (1984). Quantitative analysis of gelation in egg protein systems. Food Technology, 38(5), 67-96.

4. Weijers, M., Van De Velde, F., Stijnman, A., Van De Pijpekamp, A., Visschers, R. W. (2006). Structure and rheological properties of acid-induced egg white protein gels. Food Hydrocolloids, 20(2-3 SPEC. ISS.), 146-159. https://doi.org/10.1016/j.foodhyd.2005.02.013

5. Nys, Y. (2011). Improving the safety and quality of eggs and egg products. Chapter in a book: Egg chemistry, production and consumption Woodhead Publishing Limited. 2011.

6. Abeyrathne, E. D. N. S., Lee, H. Y., Ahn, D. U. (2013). Egg white proteins and their potential use in food processing or as nutraceutical and pharmaceutical agents-A review. Poultry Science, 92(12), 3292-3299. https://doi.org/1010.3382/ ps.2013-03391

7. Rossi, M., Casiraghi, E., Primavesi, L., Pompei, C., Hidalgo,

A. (2010). Functional properties of pasteurised liquid whole egg products as affected by the hygienic quality of the raw eggs. LWT - Food Science and Technology, 43(3), 436-441. https://doi. org/10.1016/j.lwt.2009.09.008

8. Mine, Y. (1995). Recent advances in the understanding of egg white protein functionality. Trends in Food Science and Technology, 6(7), 225-232. https://doi.org/10.1016/S09242244(00)89083-4

9. Schaafsma, G. (2000). The Protein Digestibility-Corrected Amino Acid Score. The Journal of Nutrition, 130(7), 1865S-1867S. https://doi.org/10.1093/jn/130.7.1865S

10. Vani, B., Zayas, J. F. (1995). Foaming properties of selected plant and animal proteins. Journal of Food Science, 60(5), 10251028. https://doi.org/10.1111/j.1365-2621.1995.tb06285.x

11. Matringe, E., Phan Tan Luu, R., Lorient, D. (1999). Functional properties of milk-egg mixtures. Journal of Food Science, 64(5), 787-791. https://doi.org/10.1111/j.1365-2621.1999. tb15912.x

12. Pernell, C. W., Foegeding, E. A., Luck, P. J., Davis, J. P. (2002). Properties of whey and egg white protein foams. Colloids and Surfaces A: Physicochemical and Engineering Aspects, 204(1-3), 9-21. https://doi.org/10.1016/S0927-7757(01)01061-5

13. Foegeding, E. A., Luck, P. J., Davis, J. P. (2006). Factors determining the physical properties of protein foams. Food Hydrocolloids, 20(2-3 SPEC. ISS.), 284-292. . https://doi.org/10.1016/j. foodhyd.2005.03.014 
14. Davis, J. P., Foegeding, E. A. (2007). Comparisons of the foaming and interfacial properties of whey protein iso-late and egg white proteins. Colloids and surfaces B: Biointerfaces, 54(2), 200-210. https://doi.org/10.1016/j.colsurfb.2006.10.017 15. Foegeding, E. A., Davis, J. P. (2011). Food protein functionality: A comprehensive approach. Food Hydrocolloids, 25(8), 18531864. https://doi.org/10.1016/j.foodhyd.2011.05.008

16. Nakamura, R. (1963). Studies on the foaming property of the chicken egg white. Agricultural and Biological Chemistry, 27(6), 427-432. https://doi.org/10.1271/bbb1961.27.427

17. Johnson, T. M., Zabik, M. E. (1981). Egg albumen proteins interactions in an angel food cake system. Journal of Food Science, 46(4), 1231-1236. https://doi.org/10.1111/j.1365-2621.1981. tb03029.x

18. Lechevalier, V., Croguennec, T., Pezennec, S., Guérin-Dubiard, C., Pasco, M., Nau, F. (2005). Evidence for synergy in the denaturation at the air-water interface of ovalbumen, ovotransferrin and lysozyme in ternary mixture. Food Chemistry, 92(1), 79-87. https://doi.org/10.1016/j.foodchem.2004.07.006

19. Le Floch-Fouéré, C., Beaufils, S., Lechevalier, V., Nau, F., Pézolet, M., Renault, A. et al. (2010). Sequential adsorption of egg-white proteins at the air-water interface suggests a stratified organization of the interfacial film. Food Hydrocolloids, 24(4), 275-284. https://doi.org/10.1016/j.foodhyd.2009.10.006

20. Lechevalier, V., Périnel, E., Jeantet, R., Lesaffre, C., Croguennec, T., Guérin-Dubiard, C. et al. (2005). Statistical analysis of effects of industrial processing steps on functional properties of pasteurised liquid egg white. Journal of the Science of Food and Agriculture, 85(5), 757-769. https://doi.org/10.1002/jsfa.2042 21. Nakamura, R., Sato, Y. (1964). Studies on the foaming property of the chicken egg white. Agricultural and Biological Chemistry, 28(8), 530-534. https://doi.org/10.1271/bbb1961.28.530 22. Sauveur, B., Zybko, A., Colas, B., Garreau, M., Rocard, J. (1979). Protéines alimentaires et qualité de l'œuf. I. - Effet de quelques protéines sur la qualité interne de l'œuf et les propriétés fonctionnelles, Food protein and egg quality. I. Effect of some proteins on the internal quality of the egg and the functional properties. Annales de Zootechnie, 28(3), 271-295. https://doi. org/10.1051/animres:19790305 (In French)

23. Chen, Y., Sheng, L., Gouda, M., Ma, M. (2019). Studies on foaming and physicochemical properties of egg white during cold storage. Colloids and Surfaces A: Physicochemical and Engineering Aspects, 582, Article 123916. https://doi.org/10.1016/j.colsurfa.2019.123916

24. Filipiak-Florkiewicz, A., Deren, K., Florkiewicz, A., Topolska, K., Juszczak, L., Cieślik, E. (2017). The quality of eggs (organic and nutraceutical vs. conventional) and their technological properties. Poultry Science, 96(7), 2480-2490. https://doi. org/10.3382/ps/pew488

25. Marzec, A., Damaziak, K., Kowalska, H., Riedel, J., Michalczuk, M., Koczywas, E. et al. (2019). Effect of hens age and storage time on functional and physiochemical properties of eggs. Journal of Applied Poultry Research, 28(2), 290-300. https://doi. org/10.3382/japr/pfy069

26. Hammershøj, M., Qvist, K. B. (2001). Research note: Importance of hen age and egg storage time for egg albumen foaming. LWT - Food Science and Technology, 34(2), 118-120. https://doi.org/10.1006/fstl.2000.0750

27. Wang, G., Wang, T. (2009). Effects of yolk contamination, shearing, and heating on foaming properties of fresh egg white. Journal of Food Science, 74(2), C147-C156. https://doi. org/10.1111/j.1750-3841.2009.01054.x

28. Cunningham, F. E., Garibaldi, J. A., Ijichi, K., Lineweaver, H. (1965). Pasteurization of liquid egg white. World's Poultry Science Journal, 21(4), 365-369. https://doi.org/10.1079/ WPS19650041

29. Ferreira, M., Behringer, R., Jost, R. (1995). Instrumental method for characterizing protein foams. Journal of Food Science, 60(1), 90-93. https://doi.org/10.1111/j.1365-2621.1995. tb05613.x

30. Hill, W.M., Cotterill, O.J., Funk, E.M., Baldwin, R.E. (1965). Spray-drying egg white at various pH levels. Poultry Science, 44, 1155-1163. https://doi.org/10.3382/ps.0441155

31. Clark, A. H., Kavanagh, G. M., Ross-Murphy, S. B. (2001). Globular protein gelation- theory and experiment. Food Hydrocolloids, 15(4-6), 383-400. https://doi.org/10.1016/S0268005X(01)00042-X

32. Raikos, V., Campbell, L., Euston, S. R. (2007). Rheology and texture of hen's egg protein heat-set gels as affected by $\mathrm{pH}$ and the addition of sugar and/or salt. Food Hydrocolloids, 21(2), 237244. https://doi.org/10.1016/j.foodhyd.2006.03.015
33. Ho, T. M., Zhu, J., Bansal, N., Boyce, M. C., Le, T. T. (2021). Effect of $\mathrm{pH}$ and heat treatment on physicochemical and functional properties of spray-dried whey protein concentrate powder. International Dairy Journal, 119, Article 105063. https://doi. org/10.1016/j.idairyj.2021.105063

34. Khemakhem, M., Attia, H., Ayadi, M. A. (2019). The effect of $\mathrm{pH}$, sucrose, salt and hydrocolloid gums on the gelling properties and water holding capacity of egg white gel. Food Hydrocolloids, 87, 11-19. doi:10.1016/j.foodhyd.2018.07.041

35. Totosaus, A., Montejano, J. G., Salazar, J. A., Guerrero, I. (2002). A review of physical and chemical protein-gel induction. International Journal of Food Science and Technology, 37(6), 589601. https://doi.org/10.1046/j.1365-2621.2002.00623.x

36. Holt, D. L., Watson, M. A., Dill, C. W., Alford, E. S., Edwards, R. L., Diehl, K. C. et al. (1984). Correlation of the rheological behavior of egg albumen to temperature, $\mathrm{pH}$, and $\mathrm{NaCl}$ concentration. Journal of Food Science, 49(1), 137-141. https://doi. org/10.1111/j.1365-2621.1984.tb13690.x

37. Woodward, S. A., Cotterill, 0. J. (1986). Texture and microstructure of Heat-Formed egg white gels. Journal of Food Science, 51(2), 333-339. https://doi.org/10.1111/j.1365-2621.1986. tb11123.x

38. Woodward, S.A. (1990). Egg protein gels. Chapter in a book: Food gels. London: Elsevier Applied Science, 1990.

39. Croguennec, T., Nau, F., Brulé, G. (2002). Influence of pH and salts on egg white gelation. Journal of Food Science, 67(2), 608614. https://doi.org/10.1111/j.1365-2621.2002.tb10646.x

40. Doi, E. (1993). Gels and gelling of globular proteins. Trends in Food Science and Technology, 4(1), 1-5. https://doi. org/10.1016/S0924-2244(05)80003-2

41. Ma, C.-Y., Holme, J. (1982). Effect of chemical modifications on some physicochemical properties and heat coagulation of egg albumen. Journal of Food Science, 47(5), 1454-1459. https://doi.org/10.1111/j.1365-2621.1982.tb04959.x

42. Kitabatake, N., Shimizu, A., Doi, E. (1988). Preparation of Heatinduced transparent gels from egg white by the control of $\mathrm{pH}$ and ionic strength of the medium. Journal of Food Science, 53(4), 10911095. https://doi.org/10.1111/j.1365-2621.1988.tb13537.x 43. Ruiz, B. (2015). Debut of cutting edge and healthy egg products in Spain. Retrieved from: https://www.wattagnet.com/ articles/24567-debut-of-cutting-edge-and-healthyegg-products-in-spain Accessed March 15, 2022

44. Nwaru, B. I., Hickstein, L., Panesar, S. S., Roberts, G., Muraro, A., Sheikh, A. (2014). Prevalence of common food allergies in europe: A systematic review and meta-analysis. Allergy: European Journal of Allergy and Clinical Immunology, 69(8), 992-1007. https://doi.org/10.1111/all.12423

45. Stefanova, I.L., Klimenkova, A. Yu. (2016). The technology substantiation of coagulated egg white processing and products based on it. Poultry and poultry products, 3, 37-40. (In Russian)

46. Álvaro, M., García-Paba, M. B., Giner, M. T., Piquer, M., Domínguez, O., Lozano, J. et al. (2014). Tolerance to egg proteins in egg-sensitized infants without previous consumption. Allergy: European Journal of Allergy and Clinical Immunology, 69(10), 1350-1356. https://doi.org/10.1111/all.12483

47. Moneret-Vautrin, D. A. (1998). Modifications of allergenic potency bound to food technologies. Allergie Et Immunologie, 30(1), 9-13.

48. Guchin, I.S. (2019). Allergy - late product of the immune system evolution. Immunologiya. 40(2), 43-57. https://doi. org/10.24411/0206-4952-2019-12007 (In Russian)

49. Mine, Y., Zhang, J. W. (2002). Comparative studies on antigenicity and allergenic potency of native and denatured egg white proteins. Journal of Agricultural and Food Chemistry, 50(9), 2679-2683. https://doi.org/10.1021/jf0112264

50. Hasan, S. A., Wells, R. D., Davis, C. M. (2013). Egg hypersensitivity in review. Allergy and Asthma Proceedings, 34(1), 26-32. https://doi.org/10.2500/aap.2013.34.3621

51. Sidorova, Yu.S., Mazo, V.K., Zorin, S.N., Stefanova, I.L. (2018). The evaluation of biological value and immunochemical characteristics of the coagulated chicken egg white. Problems of Nutrition, 87(1), 44-50. https://doi.org/10.24411/0042-88332018-10005 (In Russian)

52. Stefanova, I.L., Mazo, V.K., Kavtarashvili, A. Sh., Mokshantseva, I.V. (2018). Development of complex technology of production of functional egg products. Poultry and poultry products, 2. 2427. https://doi.org/10.30975/2073-4999-2018-20-2-24-27 (In Russian)

53. Stefanova, I.L., Shakhnazarova, L.V., Klimenkova, A. Yu., Kozak, S.S. (2018) Development of new types of products based on 
egg white. Poultry and poultry products, 3, 38-40. https://doi. org/10.30975/2073-4999-2018-20-3-38-40 (In Russian)

54. Stefanova, I.L., Mazo, V.K., Kavtarashvili, A. Sh., Shakhnazarova, L.V., Klimenkova, A. Yu. (2019). Technology of production of new egg products fortified with functional ingredients. Poultry and poultry products, 1, 19-22. https://doi.org/10.30975/20734999-2019-21-1-19-22 (In Russian)

55. Stefanova, I.L., Mazo, V.K., Kropacheva, E.V., Klimenkova, A. Yu. (2020). Study of the sorption processes of granberry juice polyphenols on a coagulated protein matrix. Poultry and poultry products, 4, 62-65. https://doi.org/10.30975/2073-49992020-22-4-62-65 (In Russian)

56. Stefanova, I.L., Klimenkova, A. Yu., Shakhnazarova, L.V. (2020). Chopped ready-to-cook product development from broiler meat with enhanced content of hen egg protein. Meat Industry, 6, 16-21. https://doi.org/10.37861/2618-8252-2020-6-1621 (In Russian)

57. Stefanova, I.L., Shakhnazarova, L.V., Klimenkova, A. Yu., Sorokina, I.M. (2020). Different heating types effect on biological value traits changing of ready-to-cook products from broiler meat and egg components. Vsyo o myase, 2, 56-60. https://doi.org/10.21323/2071-2499-2020-2-56-60 (In Russian)

58. Shakhnazarova, L.V., Stefanova, I.L., Klimenkova, A. Yu. Mazo, V.K. (2020). The use of coagulated egg protein in the development of functional products based on poultry. Meat Industry, 12, 22-25. https://doi.org/ 10.37861/2618-8252-2020-1122-25 (In Russian)

\section{AUTHOR INFORMATION}

Isabella L. Stefanova - doctor of technical sciences, chief researcher, Laboratory of Infant And Special Poultry Products, All-Russian Scientific Research Institute of Poultry Processing Industry - Branch of the Federal State Budget Scientific Institution Federal Scientific Center "AllRussian Research and Technological Poultry Institute" of Russian Academy of Sciences. Rzhavki township, 142552, Moscow region, Russia. Tel.: +7-499-110-28-23(4-67), E-mail: dp@vniipp.ru ORCID: https://orcid.org/0000-0002-4394-5149

* corresponding author

Anastasia Yu. Klimenkova - senior researcher, Laboratory of Infant And Special Poultry Products, All-Russian Scientific Research Institute of Poultry Processing Industry - Branch of the Federal State Budget Scientific Institution Federal Scientific Center "All-Russian Research and Technological Poultry Institute" of Russian Academy of Sciences. Rzhavki township 142552, Moscow region, Russia. Tel.: +7-499-110-28-23 (4-67), E-mail: dp@vniipp.ru

ORCID: https://orcid.org/0000-0002-3272-9467

Liudmila V. Shakhnazarova - candidate of technical sciences, senior researcher, Laboratory of Infant And Special Poultry Products, All-Russian Scientific Research Institute of Poultry Processing Industry - Branch of the Federal State Budget Scientific Institution Federal Scientific Center "All-Russian Research and Technological Poultry Institute" of Russian Academy of Sciences. Rzhavki township 142552, Moscow region, Russia. Tel: +7-499-110-28-23(4-67), E-mail: dp@vniipp.ru

ORCID: https://orcid.org/0000-0001-5671-6495

Vladimir K. Mazo - doctor of biological sciences, professor, leading researcher, Laboratory of Infant And Special Poultry Products, All-Russian Scientific Research Institute of Poultry Processing Industry - Branch of the Federal State Budget Scientific Institution Federal Scientific Center "All-Russian Research and Technological Poultry Institute" of Russian Academy of Sciences. Rzhavki township 142552, Moscow region, Russia. Tel: +7-499-110-28-23(4-67), E-mail: mazo@ionl.ru

ORCID: https://orcid.org/0000-0002-3237-7967

All authors bear responsibility for the work and presented data.

All authors made an equal contribution to the work.

The authors were equally involved in writing the manuscript and bear the equal responsibility for plagiarism.

The authors declare no conflict of interest. 